\title{
Illegal primate trade in Indonesia exemplified by surveys carried out over a decade in North Sumatra
}

\author{
Chris R. Shepherd* \\ Oxford Wildlife Trade Research Group, Oxford Brookes University, School of Social Sciences and Law, Oxford OX3 0BP, UK \\ Present address: TRAFFIC Southeast Asia, Unit 3-2, 1st floor, Jalan SS23/11, Taman SEA, Petaling Jaya, Selangor, Malaysia
}

\begin{abstract}
The illegal and unsustainable trade in primates is increasingly recognized as an urgent threat to their conservation. From 1997 to 2008, 66 surveys were conducted at bird markets in Medan, North Sumatra, where primates are sold openly. In total,1953 primates of 10 species were observed, the most common of which were the long-tailed macaque Macaca fascicularis (774 ind.), the greater slow loris Nycticebus coucang (714 ind.) and the pig-tailed macaque $M$. nemestrina (380 ind.). Six of the species observed are totally protected in Indonesia, yet were openly traded. Trade in the remaining 4 species is regulated through a harvest and trade quota system, but no quotas are allotted for them to be traded as pets. Therefore, all trade in primates observed in these markets is deemed illegal. The Indonesian authorities should be encouraged to take action against this illegal trade in Medan. Markets selling illegal wildlife should be closed down, and individuals found illegally trading in primates should be prosecuted.
\end{abstract}

KEY WORDS: CITES · Conservation $\cdot$ Primates $\cdot$ Wildlife trade

Resale or republication not permitted without written consent of the publisher

\section{INTRODUCTION}

As illegal and unsustainable trade is increasingly recognized as an urgent threat to conservation, more attention is being given to the issue (Nooren \& Claridge 2001, Grieser-Johns \& Thomson 2005, Shepherd 2006), seeking solutions to end what can only be described as a conservation crisis. Nowhere is this more apparent than in Asia (Oldfield 2003, Davies 2005). While much of the trade is conducted in a legal manner, illegal trade is rife and is often carried out openly, indicating low levels of implementation and enforcement of wildlife laws and regulations (Nijman 2005a, Shepherd 2006, Ng \& Nemora 2007, Shepherd \& Nijman 2007).

Among the numerous species in trade, primates are among the most familiar. Primates provoke an emotional response from people in most cultures, perhaps due to their kinship with humans, and are therefore the focus of many well-publicized research activities, campaigns and conservation efforts (Eudey 1987,
Cowlishaw \& Dunbar 2000, Nijman 2009). Despite this attention, many primate species are increasingly threatened, with habitat loss, together with illegal and unsustainable trade, being the primary causes (Nijman 2005a,b, Geissmann et al. 2006, Wich et al. 2008).

Primates are traded for a number of reasons, including for pets, consumption, use in traditional medicines, bio-medical research and for zoos, wildlife collections and the entertainment industry (Kavanagh 1984, Nijman $2005 a, b)$. One of the most important sources of primates to meet these demands is Southeast Asia (Kavanagh 1984, Soehartono \& Mardiastuti 2002), and Indonesia features prominently on the list of source countries for both domestic and international trade.

There are 70 species of primates in Southeast Asia. Of these, more than half are found in Indonesia, the largest archipelago in the world, with $\sim 39$ species described to date (Groves 2001, Nijman \& Meijaard 2008). Indonesia's primates are threatened to varying degrees by habitat loss, hunting for consumption and 
use in traditional medicines and capture for the pet trade, as well as for display in zoos and public animal collections (Nijman 2005a,b).

Indonesia has sufficient national legislation in place to control and regulate the trade in primates, yet enforcement of these regulations is not sufficient (Shepherd 2006, Ng \& Nemora 2007, Shepherd \& Nijman 2007). Totally protected species, i.e. those not allowed in trade, are covered by national legislation under Act of the Republic of Indonesia No. 5 of 1990 concerning Conservation of Living Resources and their Ecosystems, widely known as 'UU No. 5' or 'Act No. 5' (see Table 2). Harvest and trade in species not listed as totally protected is permitted, following an extensive harvest and export quota system to supply both domestic and international markets, regardless of whether the species are listed in Appendices II or III of the Convention on International Trade in Endangered Species of Endangered Fauna and Flora (CITES). Dealers intending to sell non-protected primates locally also require a permit from the authorities. There are no export quotas for species listed in Appendix I of CITES (all commercial international trade in these species is prohibited) or protected by Indonesia's national legislation. According to the national quota, no primates may be harvested for commercial purposes.

Indonesia has further committed to protecting primates by becoming a Party to CITES. All (non-human) primates are listed in the Appendices of CITES. Indonesia has been Party to CITES since 1978 (CITES entered into force in Indonesia in March 1979). The Directorate General of Forest Protection and Nature Conservation (PHKA) is the CITES Management Authority, charged with the administration of the Convention, and is enforced at a provincial or district level by the Natural Resources Conservation Agency (BKSDA). BKSDA is also the agency responsible for enforcing national legislation at a provincial or district level.

Primates have been commercially exported from Indonesia for decades. The international trade has included a wide variety of species, including those that were nationally protected, such as orang-utans Pongo spp. and gibbons Hylobates spp. and Symphalangus syndactylus, but the scale of the illegal trade declined after enforcement efforts on the part of the government were increased in the mid-1980s (Soehartono \& Mardiastuti 2002).

Some species have continued to be legally exported from Indonesia, with the vast majority of these being long-tailed macaques Macaca fascicularis for use in bio-medical research (Soehartono \& Mardiastuti 2002). Since the 1970s, Indonesia has been a major exporter of primates, with record levels of long-tailed macaque exports peaking in the late 1980s at more than 16000 ind.
In most years, official quota levels were illegally exceeded, triggering the Indonesian CITES Management Authority to increase the quotas (Soehartono \& Mardiastuti 2002). In the early 1990s, the international demand apparently declined, and therefore national harvest quotas were reduced. Around the same time, the international markets began to request that suppliers provide pedigrees of the specimens, and as a result, the first long-tailed macaque breeding operations were established in Indonesia, the first being set up in 1987 and more following over the next few years (Soehartono \& Mardiastuti 2002).

Apart from the commercial trade for biomedical purposes, primates are widely traded as pets throughout Indonesia (Malone et al. 2003, Shepherd et al. 2004, Nijman 2005a,b, Geissmann et al. 2006). Far more species of primates in Indonesia are traded as pets than for other reasons such as bio-medical research or even consumption. Furthermore, the bulk of the trade in Indonesia's primates for pets is to supply local demand. In this case study, I examine the trade in primates in the province of North Sumatra, and consider aspects such as the species' conservation status, current regulations and legislation and make recommendations for improved enforcement-related conservation efforts.

\section{MATERIALS AND METHODS}

Sixty-six surveys were carried out in bird markets (where primates are also sold) in Medan, North Sumatra. While Medan is the third largest city in Indonesia, its bird markets are comparable to those found throughout western Indonesia, including in Pekanbaru (Sumatra), Surabaya (Java) and Denpasar (Bali), but smaller than the major market in Jakarta (Java). Monthly surveys were carried out from 1997 to 2001 (inclusive) and on an ad hoc basis until 2008, with the last surveys carried out in October 2008. The island of Sumatra and off-lying islands harbour 18 species (Groves 2001, Nijman \& Meijaard 2008). During each survey, all primate species, whether native to Sumatra or not, were recorded.

Unstructured interviews were carried out with all dealers in the bird markets during this survey, with questions regarding trends and sources being asked, as in the studies by Shepherd et al. (2004), Shepherd (2007) and Schoppe (2009). Primates were openly displayed in the markets, and there was no need to resort to undercover techniques. No primates were purchased during this study.

Additional data on the trade in primates were collected from published and unpublished literature, as noted in the 'Discussion'. Information regarding the annual harvest and export quota was obtained from the PHKA. 


\section{RESULTS}

The national quotas set for 2008 stipulate that the only Sumatran primates that may be harvested from the wild are the long-tailed macaque Macaca fascicularis and the pig-tailed macaque $M$. nemestrina for use in captive breeding operations only. They cannot be sold as pets and they cannot be exported (Table 1).

During 66 surveys carried out in the markets of Medan, a total of 1953 specimens, representing 10 species, were observed, including 9 species native to Sumatra (Table 2). The ebony leaf monkey Trachypithecus auratus, native to the Indonesian islands of Java, Bali and Lombok, was the only non-Sumatran species observed during this study. On average, 30 primates were recorded per survey. Of the 10 species observed, the IUCN Red List of Threatened Species lists 4 as Endangered, 4 as Vulnerable, 1 as Near Threatened and 1 as Least Concern (IUCN 2008; Table 2).

The species most commonly observed were the longtailed macaque, the greater slow loris Nycticebus coucang and the pig-tailed macaque, with 774, 714

Table 1. Macaca fascicularis and M. nemistrina. Harvest quotas for 2 Sumatran primates in 2008 (source: Directorate General of Forest Protection and Nature Conservation 2008). The export quota for all locations is 0

\begin{tabular}{|lcccc|}
\hline \multirow{2}{*}{ Species } & Harvest & No. & \multicolumn{2}{c|}{ Total harvest } \\
& location & harvested & Sumatra & National \\
\hline Macaca fascicularis & North Sumatra & 200 & 4870 & \multirow{2}{*}{5100} \\
& West Sumatra & 1500 & & \\
& Riau & 800 & & \\
& Bengkulu & 500 & & \\
& Jambi & 200 & & \\
& South Sumatra & 1500 & & \\
& Aceh & 50 & & \\
& North Sumatra & 80 & & \\
& Jambi & 40 & & \\
Macaca nemistrina & Riau & 50 & 30 & \\
& South Sumatra & 30 & & \\
& & &
\end{tabular}

and 380 specimens of each observed, respectively (Table 2). Of these 3 species, only the greater slow loris is listed as a totally protected species by national legislation. Long-tailed and pig-tailed macaques may only be harvested in accordance with national annual quotas, but as stipulated in the quotas, they may currently only be harvested for use as breeding stock in registered captive breeding operations.

Based on available information from 1997 to 2008, the average monthly number of primates observed for sale has declined somewhat (Fig. 1). It is important to note that since 2005, the number of shops selling wildlife in the markets has also declined from approximately 30 in the late 1990s to less than 15 by 2008, apparently due to the fear of avian influenza and the resulting decline in regular customers (Shepherd 2006). During this time, however, the species composition in the market has shown no significant change (Fig. 2).

All primates recorded during this study were openly displayed for sale, and as the trade in these species was not carried out in accordance with national legislation and regulations, it can be assumed that enforcement levels are minimal. Six of the 10 species observed are totally protected by Indonesian law (Table 2). Of the remaining 4, quotas are only allotted for 2, but these are only to be used as breeding stock in registered captive breeding facilities, not for sale as pets. Dealers in Medan's bird markets claimed that high-profile (protected) species such as orangutans drew the attention of enforcement agencies, but other totally protected species, such as the greater slow loris, rarely did. Other primates, such as long-tailed and pig-tailed macaques, seem to go unnoticed by enforcement agencies.

Table 2. Primate species observed, total numbers observed and conservation status (1997 to 2008). EN: Endangered, LC: Least Concern, NT: Near Threatened, VU: Vulnerable

\begin{tabular}{|c|c|c|c|c|c|}
\hline Species & Common name & Total & $\begin{array}{c}\text { Indonesian national } \\
\text { legislation }\end{array}$ & $\begin{array}{l}\text { IUCN Red } \\
\text { List status }\end{array}$ & $\begin{array}{c}\text { CITES } \\
\text { Appendix }\end{array}$ \\
\hline Nycticebus coucang & Greater slow loris & 714 & Protected & VU & $\mathrm{I}$ \\
\hline Macaca fascicularis & Long-tailed macaque & 774 & Regulated & $\mathrm{LC}$ & II \\
\hline M. nemestrina & Pig-tailed macaque & 380 & Regulated & VU & II \\
\hline Trachypithecus cristatus & Silvered leaf monkey & 65 & Regulated & NT & II \\
\hline T. auratus & Ebony leaf monkey & 3 & Protected & VU & II \\
\hline Presbytis thomasi & Thomas's leaf monkey & 7 & Protected & VU & II \\
\hline P. melalophos & Sumatran leaf monkey & 4 & Regulated & EN & II \\
\hline Symphalangus syndactylus & Siamang & 2 & Protected & EN & $\mathrm{I}$ \\
\hline Hylobates agilis & Agile gibbon & 3 & Protected & EN & I \\
\hline H. lar & White-handed gibbon & 1 & Protected & EN & I \\
\hline
\end{tabular}




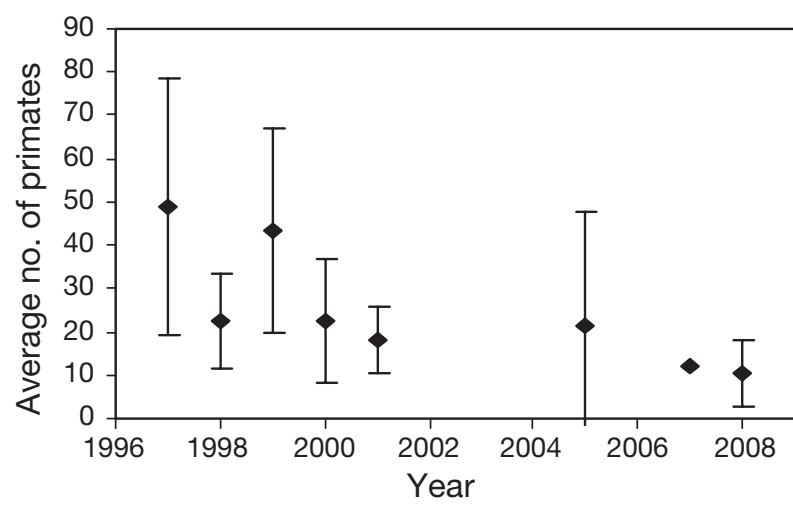

Fig. 1. Mean $( \pm \mathrm{SD})$ numbers of primates observed in Medan bird markets from 1997 to 2008 (no surveys were conducted from 2002 to 2004). The most commonly observed species were the long-tailed macaque, pig-tailed macaque and greater slow loris

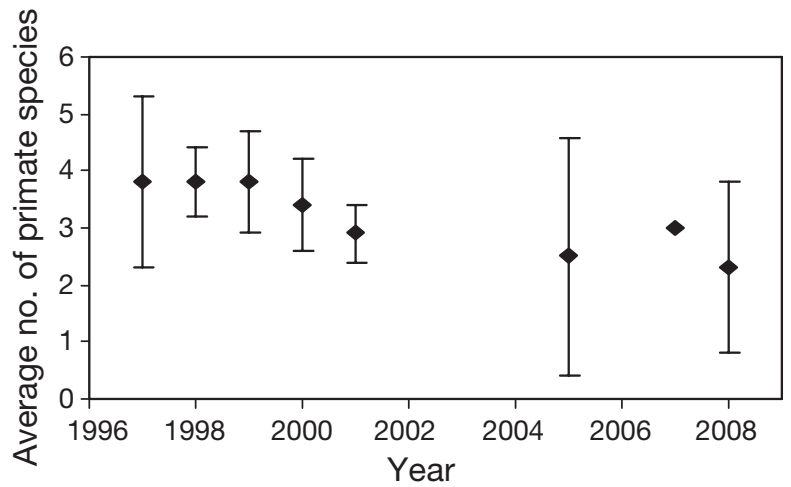

Fig. 2. Mean $( \pm \mathrm{SD})$ numbers of primate species observed in Medan bird markets from 1997 to 2008 (no surveys were conducted from 2002 to 2004). The number of species observed remained relatively constant

According to dealers in the market and from direct observations, mortality rates of some species sold as pets, such as the greater slow loris, are high, as many die from infections (after having their teeth removed with pliers), inappropriate food and stress. These animals are relatively inexpensive as far as pets go, and mortalities are not considered a serious issue. Pets such as these are viewed as being easily replaceable. Turnover was difficult to measure, but according to dealers, primates usually sell very quickly.

\section{DISCUSSION AND RECOMMENDATIONS}

Lack of resources, both financial and human, have often been identified as the major obstacles to successful enforcement actions in Indonesia (Shepherd \& Magnus 2004, Shepherd \& Ibarrondo 2005). However, the lack of substantial prosecutions is an equally serious factor, and as a result, dealers trading in illegal wildlife have little fear of prosecution (Shepherd \& Magnus 2004, Nijman 2005a, Ng \& Nemora 2007). High-profile species such as orang-utans were not openly displayed and, as was pointed out by Malone et al. (2003), it is likely that dealers are all fully aware of the national legislation protecting these species.

Indonesia has adequate legislation and regulations to protect primates from over-exploitation (Soehartono \& Mardiastuti 2002, Shepherd \& Nijman 2007). Despite these regulations, illegal capture and trade continues, and the majority of the species observed for sale during this study (representing approximately $37 \%$ of the individuals) are listed as protected in Indonesia.

Compared to the trade in primates in Java and Bali, as reported from a survey conducted in 2000 (Malone et al. 2003), the same 3 species, and in the same order, make up the 3 most commonly traded species (longtailed macaque, slow loris - although this species was not confirmed - and pig-tailed macaque). One difference between the primate trade in Java and Bali compared to Sumatra is that on the former 2 islands the Javan-Bali endemic ebony leaf monkey is commonly encountered, whereas on Sumatra its congener the silvered leaf monkey is the species more often found in trade. Malone et al. (2003) pointed out that Sumatra was a particular source area for acquiring primates to be traded in Java and, as found in the present study, suggested that there were clear links between animal traders in Java and Sumatra.

Based on available information, the number of primates observed in the bird markets in Medan has declined slightly over recent years, but this appears to be due to the impact of avian influenza rather than to fear of legal action being taken against dealers (Shepherd 2006). The species composition, regardless of legal status, did not significantly change over the period of this study. As there are no quotas for the capture and domestic trade of these species, none of the trade observed in Medan's markets was carried out in accordance with Indonesia's national regulations.

Trade in lower-profile, but totally protected species, such as the greater slow loris, continues to be carried out openly in bird markets. Trade in species not listed as totally protected, but harvested outside Indonesia's harvest and trade quota regulations, is carried out with little fear of enforcement action, as bird market dealers in Medan have never been given quotas or permits to sell primates such as long-tailed and pig-tailed macaques. This problem is not confined to primates, but is symptomatic of other taxa offered for sale in Indonesia, including birds (Shepherd 2006, 2007), reptiles (Shepherd \& Nijman 2007, Schoppe 2009) and other mammals (Shepherd 2008). 
Trade in high-profile protected species, such as orang-utans, has been driven underground due to a combination of enforcement efforts and public awareness campaigns, which largely eliminates opportunistic or compulsive buying and sends a message to the public, viz. that buying these species is illegal and is obviously a punishable offence. While the numbers of primates observed in trade during this study alone would not pose a threat to the species, it must be considered that this trade is widespread, and the numbers reported here should be considered a fraction of the total numbers in trade.

As most of the species observed are recognized as being threatened to varying degrees by the IUCN Red List of Threatened Species, taking action against the illegal capture and trade should be considered a priority for conservation and enforcement efforts. The Natural Resources Conservation Agency in North Sumatra should be encouraged to monitor these markets regularly and to take action against individuals involved in illegal capture and sale of primates. Individuals found unlawfully keeping or trading in primates should be punished to the full extent of the law. Successful prosecutions should be publicized widely by the media to serve as a deterrent for others. Wildlife markets where illegal trade in wildlife is carried out, such as the bird market in Medan, should be closed down by the relevant authorities.

Acknowledgements. I thank V. Nijman, R. Thomas and A. Nekaris for their valuable comments on an earlier draft of this paper.

\section{LITERATURE CITED}

Cowlishaw G, Dunbar RIM (2000) Primate conservation biology. University of Chicago Press, London

Davies B (2005) Black market: inside the endangered species trade in Asia. Earth Aware Editions, San Rafael, CA

Directorate General of Forest Protection and Nature Conservation (2008) Quota for wild plant harvest and capture of wild animals from natural habitats for the period of 2008 . Directorate General of Forest Protection and Nature Conservation, Jakarta

Eudey AA (1987) Action plan for Asian primate conservation: 1987-1991. IUCN/SSC (Species Survival Commission) Primate Specialist Group, Gland

Geissmann T, Nijman V, Dallmann R (2006) The fate of diurnal primates in southern Sumatra. Gibbon J 2:18-24

Grieser-Johns A, Thomson J (2005) Going, going, gone: the illegal trade in wildlife in East and Southeast Asia. World Bank, Washington, DC

Groves CP (2001) Primate taxonomy. Smithsonian Institution

Editorial responsibility: Anna Nekaris,

Oxford, UK
Press, Washington, DC

IUCN (International Union for the Conservation of Nature and Natural Resources) (2008) 2008 IUCN Red List of Threatened Species. Available at www.iucnredlist.org

Kavanagh M (1984) A review of the international primate trade. In: Mack D, Mittermeier RA (eds) The international primate trade, Vol 1. TRAFFIC, Washington, DC, p 49-62

Malone NM, Fuentes A, Purnama A, Adi Putra IMW (2003) Displaced hylobatids: biological, cultural, and economic aspects of the primate trade in Jawa and Bali, Indonesia. Trop Biodivers 8:41-49

Ng J, Nemora (2007) Tiger trade revisited in Sumatra, Indonesia. TRAFFIC Southeast Asia, Petaling Jaya

Nijman V (2005a) In full swing: an assessment of trade in orang-utans and gibbons on Java and Bali, Indonesia. TRAFFIC Southeast Asia, Petaling Jaya

Nijman V (2005b) Hanging in the balance: an assessment of trade in orang-utans and gibbons in Kalimantan, Indonesia. TRAFFIC Southeast Asia, Petaling Jaya

Nijman V (2009) An assessment of trade in gibbons and orang-utans in Sumatra, Indonesia. TRAFFIC Southeast Asia, Petaling Jaya

Nijman V, Meijaard E (2008) Zoogeography of primates in insular Southeast Asia: species-area relationships and the effects of taxonomy. Contrib Zool 77:117-126

Nooren H, Claridge G (2001) Wildlife trade in Laos: the end of the game. NC-IUCN, Amsterdam

Oldfield S (2003) The trade in wildlife. Regulation for conservation. Flora and Fauna International, Resource Africa and TRAFFIC International, London

Schoppe S (2009) Status, trade dynamics and management of the Southeast Asian box turtle Cuora amboinensis in Indonesia. TRAFFIC Southeast Asia, Petaling Jaya

Shepherd CR (2006) The bird trade in Medan, North Sumatra: an overview. Birding Asia 5:16-24

Shepherd CR (2007) Trade in the black-and-white laughingthrush Garrulax bicolor and white-crested laughing thrush G. leucolophus in Indonesia. Birding Asia 8: 49-52

Shepherd CR (2008) Civets in trade in Medan, North Sumatra, Indonesia (1997-2001) with notes on legal protection. Small Carnivore Conserv 38:34-36

Shepherd CR, Ibarrondo B (2005) The trade of the Roti Island snake-necked turtle Chelodina mccordi, Indonesia. TRAFFIC Southeast Asia, Petaling Jaya

Shepherd CR, Magnus N (2004) Nowhere to hide: the trade in Sumatran tiger. TRAFFIC Southeast Asia, Petaling Jaya

Shepherd CR, Nijman V (2007) An overview of the regulation of the freshwater turtle and tortoise pet trade in Jakarta, Indonesia. TRAFFIC Southeast Asia, Petaling Jaya

Shepherd CR, Sukumaran J, Wich SA (2004) Open season: an analysis of the pet trade in Medan, Sumatra 1997-2001. TRAFFIC Southeast Asia, Petaling Jaya

Soehartono T, Mardiastuti A (2002) CITES - implementation in Indonesia. Nagao Natural Environment Foundation (NEF), Jakarta

Wich SA, Meijaard E, Marshall AJ, Husson S and others (2008) Distribution and conservation status of the orangutan (Pongo spp.) on Borneo and Sumatra: How many remain? Oryx 42:329-339

Submitted: February 19, 2009; Accepted: February 18, 2010

Proofs received from author(s): April 15, 2010 